\title{
PARTIAL AND COMPLETE REPLACEMENT OF FISH MEAL WITH A MIXTURE OF DIFFERENT PLANT PROTEIN SOURCES IN JUVENILE MONO SEX NILE TILAPIA (Oreochromis niloticus) DIETS.
}

El-Saidy, D. M. S. ${ }^{1}$; S. H. Mahmoud ${ }^{2}$ and Hayam D. Tonsy ${ }^{2}$

1- Department of Poultry Production, Faculty of Agriculture, University of Minufiya, Shebin El-Kom, Egypt.

2- Animal Production Research Institute, Utilization By-Products Department, Agricultural Research Center, Dokki, Giza, Egypt.

\begin{abstract}
A plant protein mixture (PPM) was tested to replace fish meal (FM) in diets for juvenile mono sex Nile tilapia, Oreochromis niloticus. Fish averaging ( \pm SD) $3.27 \pm$ $0.1 \mathrm{~g}$ were divided into 15 groups. Three groups were fed each of five isonitrogenous $(30.4 \%)$ and isocaloric $\left(4.7 \mathrm{kcal} \mathrm{g}^{-1}\right)$ diets replacing $0,25,50,75$, and $100 \%$ of fish meal protein with similar percentages of PPM (PPM 0, PPM25, PPM50, PPM75, or PPMI00, respectively). The PPM consisted of $25 \%$ peanut meal, $25 \%$ okara meal, $25 \%$ canola meal and $25 \%$ corn glutein meal. After 10 weeks of feeding, fish fed diets PPM50 exhibited growth performance and feed utilization not significantly different from fish fed control diet which contained $100 \%$ fish meal protein. Incorporation of plant protein mixture in mono sex Nile tilapia diets significantly decreased moisture, protein and fat content of whole body. The highest value of lipid content was recorded with fish fed $100 \%$ plant protein mixture meal (Diet 5) and the lowest was recorded with fish fed $100 \%$ FM protein (control, Diet 1 ). Based on the results of this study PPM diets were economically superior to FM diet. Therefore, these findings suggest that up to $50 \%$ of fish meal protein can be replaced by plant protein mixture in mono sex Nile tilapia diets without any adverse effects on growth performances, feed utilization and body composition.
\end{abstract}

Keywords: Plant protein mixture, fish meal, mono sex Nile tilapia, growth performance, feed utilization and body composition.

\section{INTRODUCTION}

Various oilseed cakes and meals are produced in Egypt on a large scale as by-products of the edible oil industry. These include peanut meal, okara meal, canola meal and corn glutein meal. These oil cakes and meals are fairly rich in protein and are traditionally used as feeds for farm animals. In recent years, intensification of tilapia fry production in Egypt has made it essential to develop complete and supplemental diets for use in hatcheries and nursery ponds. Traditionally, fish meal has been the main source of protein in diets for fish fry. However, the increasing cost of fish meal has restricted its use as a protein source for fish diets. Therefore, it is a matter of urgency that alternative protein sources for tilapia diets be found.

The efficiency of various alternative protein sources as partial or complete dietary replacement for fish meal with different sources has been evaluated in fish diets, e.g. poultry by-product (Gaber 1996 and Abdelhamid et al.,2007), sunflower meal (El-Saidy and Gaber 2002a), soybean meal (ElSaidy and Gaber 1997; 2002b), linseed meal (El-Saidy and Gaber, 2001 and Abdelhamid et al.,2005a), and cottonseed meal (Middendorp and Huisman, 
1995; El-Saidy, 1999 and Mbahinzireki et al., 2001).

A significant amount of research has been conducted on the replacement of fish meal with soybean meal as protein source in feeds for Nile tilapia (El-Saidy and Gaber, 1997 and 2002b). They reported that soybean meal supplemented with $1 \%$ methionine only or $1 \%$ methionine plus $0.5 \%$ lysine can totally replace fish meal in Nile tilapia diets. In contrast to soybean meal, there is less information available on the use of other oil seed by-products meals in feeds for Nile tilapia (Abdelhamid et al., 2004a and 2005b). Oilseed cakes and meals such as linseed meal (Hossain, et al. 1997; El-Saidy and Gaber 2001), sunflower meal (Sanz et al., 1994; El-Saidy and Gaber 2002a); Cottonseed meal (El-Sayed, 1990; El-Saidy 1999; Middendrop and Huisman 1995 and Mbahinzireki et al., 2001) have been used in Nile tilapia feeds.

Peanut meal, okara meal, canola meal and corn glutein meal commonly incorporated in practical fish feeds (El-Sayed, 1999) who studied individually as plant protein replacements for fish meal. These plant by-product meals have high protein levels and favorable essential amino acids profiles, but they are deficient in one or more essential amino acids (NRC, 1993). Therefore, it is important to study the nutritional value of combinations of plant proteins in order to replace fish meal in commercial fish diets without compromising growth and feed efficiency. The purpose of this study was to evaluate growth, feed utilization and whole body composition of mono sex Nile tilapia, Oreochromis niloticus fed diets containing graded substitutions of a plant protein mixture (PPM) for fish meal (FM) protein.

\section{MATERIALS AND METHODS}

\section{Culture conditions}

Mono sex Nile tilapia fingerlings were obtained from a local fish farm (El wafaa Hatchery, El Hawamdia, Giza Governorate, Egypt). Fish were acclimated to laboratory conditions for four weeks in $1000 \mathrm{~L}$ fiberglass tank. The feeding trial was performed at the Fish Research Laboratory, College of Agriculture, Minufiya University, Egypt. At the beginning of the experiment, 15 glass aquaria $(801)$ were each stocked with 10 fish with an average weight of $3.27 \pm 0.1 \mathrm{~g}$. The aquaria were supplied with freshwater (free of chlorine) at a rate of $250 \mathrm{ml} \mathrm{min} .^{-1}$ with supplemental aeration. The aquaria were illuminated by overhead fluorescent lighting set on a $12 \mathrm{~h}$ light: $12 \mathrm{~h}$ dark cycle.

\section{Diets and feeding regime}

Five experimental diets were formulated to be isonitrogenous and isocaloric in terms of crude protein (30.4\%) and gross energy $\left(4.7 \mathrm{kcal} \mathrm{g}^{-1}\right)$. Energy value was calculated using the gross energy values for the macronutrients $(5.6 \mathrm{kcal} / \mathrm{g}$ protein, $9.5 \mathrm{kcal} / \mathrm{g}$ fat and $4.1 \mathrm{kcal} / \mathrm{g}$ carbohydrate; fiber was not included in calculation). A mixture of plant proteins used in this experiment was obtained from Minufiya University, Egypt and consisted of peanut meal, okara meal, canola meal and corn glutein meal, $25 \%$ each. The proximate composition of the ingredients used in diets formulation is given in Table 1. For the experimental diets (Table 2), FM was replaced by PPM on the basis of crude protein as follows: control, diet $1=100 \%$ FM: 0\% PPM, 
PPM25, diet $2=75 \%$ FM : 25\% PPM, PPM50, diet $3=50 \%$ FM : 50\% PPM, PPM75, diet $4=25 \% \mathrm{FM}: 75 \% \mathrm{PPM}$ and PPMI00, diet $5=100 \% \mathrm{PPM}: 0 \%$ FM. The calculated essential amino acids concentrations in the experimental diets (Table 3) met or exceeded the recommendation of Santiago and Lovell (1988) for Nile tilapia. The experimental diets were pelleted, freezedried and stored at $-20^{\circ} \mathrm{C}$ until used. Each diet was fed manually to apparent satiation twice daily for 10 weeks to triplicate groups of fish. Feed intake was recorded daily. Fish in each aquaria were weighed at the start and every two weeks of the experimental period. Feeding was stopped $24 \mathrm{~h}$ prior to weighing.

Table 1: Proximate composition of feedstuffs used in the study $(\%$ dry matter).

\begin{tabular}{lcccccc}
\hline Ingredients & Dry matter & $\begin{array}{c}\text { Crude } \\
\text { protein }\end{array}$ & Crude fat & Crude fiber & $\begin{array}{c}\text { N-free } \\
\text { extract }\end{array}$ & Ash \\
\hline Fish meal & 92.0 & 60.0 & 10.7 & 0.9 & 9.4 & 19.0 \\
Peanut meal & 90.2 & 48.0 & 6.0 & 6.6 & 34.3 & 5.1 \\
Canola meal & 90.0 & 30.0 & 3.8 & 12.0 & 47.0 & 7.2 \\
Okara meal & 95.9 & 34.5 & 18.8 & 20.6 & 22.2 & 3.9 \\
Corn glutein meal & 90.0 & 60.0 & 2.2 & 2.0 & 34.2 & 1.6 \\
Mixture plant & 91.5 & 43.1 & 7.7 & 10.3 & 34.4 & 4.5 \\
protein & & & & & &
\end{tabular}

Table 2: Feed formulation and proximate composition of diets used in the present study.

\begin{tabular}{|c|c|c|c|c|c|}
\hline \multicolumn{6}{|c|}{ Diets } \\
\hline Items & $\begin{array}{l}1 \text { (Control) } \\
(0 \% \mathrm{PM})\end{array}$ & $\begin{array}{c}2 \\
(25 \% \text { PPM) }\end{array}$ & $\begin{array}{c}3 \\
(50 \% \text { PPM) }\end{array}$ & $\begin{array}{c}4 \\
\text { (75\% PPM) }\end{array}$ & $\begin{array}{c}5 \\
(100 \% \text { PM) }\end{array}$ \\
\hline \multicolumn{6}{|l|}{ Ingredient (\%) } \\
\hline FM (60 \% C. P.) & 20.00 & 15.00 & 10.00 & 5.00 & 0.00 \\
\hline PPM (43.1 \% C.P.) & 0.00 & 6.96 & 13.91 & 20.87 & 27.82 \\
\hline Soybean meal (44\% CP) & 35.00 & 35.00 & 35.00 & 35.00 & 35.00 \\
\hline Yellow corn meal & 20.00 & 19.04 & 18.09 & 16.13 & 16.18 \\
\hline Wheat bran & 10.50 & 10.50 & 10.50 & 10.50 & 10.50 \\
\hline Corn starch & 5.50 & 4.50 & 3.50 & 3.50 & 1.50 \\
\hline Fish oil & 4.00 & 4.00 & 4.00 & 4.00 & 4.00 \\
\hline Molasses & 2.00 & 2.00 & 2.00 & 2.00 & 2.00 \\
\hline Vit. \& Min.Premix' & 2.00 & 2.00 & 2.00 & 2.00 & 2.00 \\
\hline Vitamin $\mathrm{C}^{2}$ & 0.10 & 0.10 & 0.10 & 0.10 & 0.10 \\
\hline Di Ca Phosphate & 1.40 & 1.40 & 1.40 & 1.40 & 1.40 \\
\hline Total (\%) & 100.00 & 100.00 & 100.00 & 100.00 & 100.00 \\
\hline Proximate analysis $(\%)^{3}$ & 7.87 & 8.23 & 8.48 & 8.38 & 8.28 \\
\hline Moisture & 30.60 & 30.50 & 30.40 & 30.23 & 30.23 \\
\hline Crude protein & 14.60 & 14.72 & 15.04 & 15.01 & 14.78 \\
\hline Crude fat & 7.95 & 8.70 & 8.49 & 9.39 & 9.55 \\
\hline Ash & 6.22 & 7.23 & 7.33 & 7.43 & 7.46 \\
\hline Crude fiber & 32.76 & 30.62 & 30.26 & 29.56 & 29.70 \\
\hline $\mathrm{NFE}^{4}$ & 4.70 & 4.70 & 4.70 & 4.70 & 4.70 \\
\hline $\begin{array}{l}\text { Gross Energy (kcal/g } \\
\text { diet)5 }\end{array}$ & 7.87 & 8.23 & 8.48 & 8.38 & 8.28 \\
\hline
\end{tabular}

I Premix supplied according to Xie, et al. (1997).

2 Phospitan C (Mg-L-ascorbyl-2-phosphate); Showa Denko K. K., Tokyo, Japan.

3 Values represent the mean of three sample replicates (as fed).

4 NFE (Nitrogen free extract) = 100 - (\% moisture + $\%$ protein $+\%$ fat $+\%$ fiber $+\%$ ash $)$.

5 Gross energy calculated according to Sanz, et al. (1994). 
El-Saidy, D. M. S. et al.

Table 3: Calculated amino acids composition of diets used in the study (g per $100 \mathrm{~g}$ diet).

\begin{tabular}{lcccccc}
\hline & \multicolumn{7}{c}{ Diets } & & & & \\
\cline { 2 - 7 } & 1 & 2 & 3 & 4 & 5 & Required $^{\mathbf{1}}$ \\
\hline Indispensable amino acids & & & & & & \\
(IAA) $^{2}$ & & & & & & \\
Arginine & 2.08 & 2.44 & 2.86 & 3.29 & 3.63 & 1.33 \\
Histidine & 0.84 & 0.96 & 0.98 & 1.06 & 1.13 & c 0.54 \\
Isoleucine & 1.59 & 1.62 & 1.91 & 2.08 & 2.24 & 0.99 \\
Leucine & 2.73 & 2.68 & 2.61 & 2.54 & 2.48 & 1.09 \\
Lysine & 2.48 & 3.01 & 2.43 & 2.17 & 1.90 & 1.63 \\
Methionine & 1.05 & 1.36 & 1.28 & 1.20 & 1.11 & 1.02 \\
Phenylalanine & 1.42 & 1.45 & 1.48 & 1.51 & 1.53 & 1.82 \\
Threonine & 1.40 & 1.42 & 1.46 & 1.50 & 1.54 & 1.15 \\
Tryptophane & 0.37 & 0.41 & 0.47 & 0.53 & 0.58 & 0.32 \\
Valine & 1.81 & 1.83 & 1.90 & 1.96 & 2.01 & 1.09 \\
\hline
\end{tabular}

From Santiago and Lovell (1988).

2Data obtained from National Research Council (1993).

\section{Growth study}

At the beginning of the growth study, 15 fish were sampled and stored at $-20^{\circ} \mathrm{C}$ for analysis of whole body composition. At the end of the growth study (10 weeks), four fish per tank were withdrawn and frozen at $-20^{\circ} \mathrm{C}$ till analysis. Growth performances were determined according to Cho \& Kaushik (1985) as follows:

SGR $($ specific growth rate) $=100$ (In final weight - In initial weight) $/$ No of days).

FER (feed efficiency ratio) $=$ wet weight gain $(\mathrm{g}) /$ dry feed intake $(\mathrm{g})$.

FCR (feed conversion ratio) $=$ dry feed intake $(\mathrm{g}) /$ wet weight gain $(\mathrm{g})$.

PER $($ protein efficiency ratio $)=$ weight gain $(\mathrm{g}) /$ protein intake $(\mathrm{g})$.

\section{Water quality}

Water temperature was recorded daily in one tank using a mercury thermometer suspended at $30 \mathrm{~cm}$ water depth. Dissolved oxygen (DO) was measured using an YSI model 56 oxygen meter (Yellow Springs Instrument Company, Yellow Springs, Ohio, USA) and $\mathrm{pH}$ by a $\mathrm{pH}$ meter (pH pen Fisher Scientific, $\mathrm{OH}, \mathrm{USA}$ ). Ammonia and nitrite were measured at weekly intervals in one tank per dietary treatment according to (Golterman, et al., 1978). Sampling was performed between 0700 and $0800 \mathrm{~h}$.

\section{Analytical methods}

Analysis of samples was made as follows: dry matter after desiccation in an oven $\left(105^{\circ} \mathrm{C}\right.$ for $24 \mathrm{~h}$ ); ash (incineration at $550^{\circ} \mathrm{C}$ for $12 \mathrm{~h}$ ); crude protein (micro kjeldahl, $\mathrm{N} \times 6.25$ ); crude fat (ether extraction by Soxhelt method); and crude fiber (for diets and their ingredients only) according to AOAC (1995).

\section{Statistical analysis}

The data were analyzed by one-way analysis of variance (SAS, Institute Inc, 1993). Duncan's multiple range test was used to compare differences among individual means. Treatment effects were considered significant at $P \leq 0.05$. All percentage and ratio were transformed to arcsin values before analysis (Zar, 1984). 


\section{RESULTS AND DISCUSSION}

In the present study, water quality parameters were as follows: water temperature ranged from 27.4 to $28.2 \mathrm{QC}$, dissolved oxygen 4.2 to $4.5 \mathrm{mg} \mathrm{l}^{-1}$, $\mathrm{pH} 7.4$ to 7.8 , alkalinity 165 to $175 \mathrm{mg} \mathrm{l}^{-1}$ and total ammonia 0.39 to $0.42 \mathrm{mg}$ $\mathrm{I}^{-1}$. There were no significant differences in water quality parameters among the treatments during the whole experimental period. Water quality parameters were found to be within the acceptable range for tilapia growth (Stickney, 1979).

The present study demonstrated the potential of four plant protein meals for inclusion in commercial Nile tilapia feeds. As well as being of immediate importance for feed production in Egypt. There is little information in the scientific literature concerning the use of plant protein mixture in Nile tilapia feeds, particularly feeds produced under commercial conditions. Since tilapia production is in excess of $45 \%$ of annually fish produced in Egypt (CAPMS 1994). There is considerable benefit related to the replacement of part of the fish meal currently used in feeds.

The results of average final body weight, specific growth rate (SGR), weight gain \%, feed conversion ratio (FCR) and protein efficiency ratio (PER) are presented in Table 4. Fish fed diet 2 which contained 25\% PPM meal showed the best average final body weight, (SGR), weight gain \%, (FCR), and (PER). However, the same parameters for fish fed diet 3 did not differ significantly from those of fish fed diet 1 (control diet). Diet 5 which contained $100 \%$ PPM meal resulted in the lowest significantly average final body weight, (SGR), weight gain \%, (FCR), and (PER). The unsuitability of substitution at this level was further reflected by the lack of response of the fish to the test diet at feeding times. The survival rate at the end of the feeding trail was high and recorded more than $98 \%$ for all groups of fish fed the experimental diets. In the present study, fish fed diet 2 (25\% PPM) had faster growth rate and better food utilization than fish fed diet 5 (100\% PPM). Fish fed diets $3(50 \%$ PPM) did not differ significantly $(P>0.05)$ from those of fish fed control diet 1 (100\% fish meal protein).

The present study exhibited that PPM meal can replace fishmeal protein up to $50 \%$ in practical diets of mono sex Nile tilapia. This is in agreement with the results of Jackson et al. (1982), who fed S. mossambicus (13.9 g) isocaloric, isonitrogenous diets with varying levels of plant protein from cottonseed meal for 9 weeks. The best (FCR) and (SGR) were obtained at 50 $\%$ cottonseed meal. However, the fish grew at a reasonable rate even at a $100 \%$ cottonseed meal inclusion level. Similar results have been reported for Tilapia zillii (El-Sayed, 1987), Nile tilapia (El-Sayed, 1990, El-Saidy and Gaber, 2001 and El-Saidy and Saad, 2008), and Carp (Hasan et al., 1997) and, (El-Saidy et al., 2005).

In the present study, however, mono sex male Nile tilapia which has an accelerated growth in much higher water temperatures have shown very significant growth depression with plant protein mixture meal protein $50 \%$ of dietary protein (diets $4 \& 5$ ). This growth depression was further elaborated by the lack of response of the fish to the test diets at feeding times. This is in agreement with the results of Hashim et al., (1994) who reported that winged 
bean seed meal can not be used as a sole protein source for 0 . niloticus fry. Fish fed winged bean seed meal based diets exhibited poor growth performance, (FCR) and SGR. El-Saidy and Gaber (2001), El-Saidy and Saad (2008) and El-Saidy et al. (2005) reported the same trend with Nile tilapia and common carp, respectively.

The good growth, excellent condition and high survival in mono sex Nile tilapia fed diets containing PPM meal protein up to $50 \%$ in the present study demonstrated that PPM meal had no adverse effect on fish performance at this level $(50 \%)$ of PPM meal. However, increasing levels of PPM meal to $75 \%$ and $100 \%$ in the diets 4 and 5 exhibited the adverse effect.

Table 4: The effect of partial and total substitution of fish meal (FM) by plant protein meal mixture (PPM) in practical diets for Nile tilapia fingerlings on growth performances and feed utilization after 10 weeks experiment. (Values are means \pm $S^{1}$ ).

\begin{tabular}{lccccc}
\hline & \multicolumn{5}{c}{ Diets } \\
\cline { 2 - 6 } Parameters & $\mathbf{1}$ & $\mathbf{2}$ & $\mathbf{3}$ & $\mathbf{4}$ & $\mathbf{5}$ \\
\hline Initial body weight (g) & $3.24 \pm 0.1 \mathrm{a}$ & $3.26 \pm 0.2 \mathrm{a}$ & $3.27 \pm 0.2 \mathrm{a}$ & $3.31 \pm 0.1 \mathrm{a}$ & $3.25 \pm 0 . \mathrm{a}$ \\
Final body weight (g) & $17.99 \pm 0.26 \mathrm{~b}$ & $21.50 \pm 2.1 \mathrm{a}$ & $17.30 \pm 1.1 \mathrm{~b}$ & $14.63 \pm 0.31 \mathrm{c}$ & $13.09 \pm 0.23 \mathrm{c}$ \\
Weight gain (g) & $14.75 \pm 0.28 \mathrm{~b}$ & $18.27 \pm 2.1 \mathrm{a}$ & $14.06 \pm 1.1 \mathrm{~b}$ & $11.39 \pm 0.29 \mathrm{c}$ & $9.85 \pm 0.21 \mathrm{c}$ \\
Weight gain (\%) & $455.2 \pm 12.2 \mathrm{~b}$ & $560.4 \pm 68.4 \mathrm{a}$ & $430.0 \pm 36.7 \mathrm{~b}$ & $344.1 \pm 6.1 \mathrm{c}$ & $303.1 \pm 4.0 \mathrm{c}$ \\
SGR (\% / day) & $2.48 \pm 0.06 \mathrm{~b}$ & $2.7 \pm 0.15 \mathrm{a}$ & $2.39 \pm 0.10 \mathrm{~b}$ & $2.25 \pm 0.02 \mathrm{c}$ & $1.99 \pm 0.02 \mathrm{~d}$ \\
Feed intake (g / fish) & $18.12 \pm 0.02 \mathrm{ab}$ & $18.46 \pm 0.98 \mathrm{a}$ & $17.35 \pm 0.54 \mathrm{~b}$ & $15.62 \pm 0.47 \mathrm{c}$ & $14.25 \pm 0.36 \mathrm{~d}$ \\
FCR (FI/WG) & $1.23 \pm 0.02 \mathrm{~b}$ & $1.02 \pm 0.06 \mathrm{a}$ & $1.24 \pm 0.05 \mathrm{~b}$ & $1.37 \pm 0.07 \mathrm{c}$ & $1.45 \pm 0.01 \mathrm{~d}$ \\
FER (WG / Fl * 100) & $0.81 \pm 0.20 \mathrm{~b}$ & $0.99 \pm 0.06 \mathrm{a}$ & $0.81 \pm 0.04 \mathrm{~b}$ & $0.73 \pm 0.01 \mathrm{c}$ & $0.69 \pm 0.01 \mathrm{c}$ \\
PER & $2.66 \pm 0.05 \mathrm{~b}$ & $3.24 \pm 0.20 \mathrm{a}$ & $2.66 \pm 0.12 \mathrm{~b}$ & $2.41 \pm 0.01 \mathrm{c}$ & $2.29 \pm 0.01 \mathrm{c}$ \\
\hline
\end{tabular}

$\mathrm{J}$ Mean in the same row bearing different superscript letter differ significantly $(\mathbf{P}:<; 0.05)$.

In the present study, the proximate composition of the experimental fish at the start and the termination of the feeding trial are shown in Table 5. Moisture, protein and ash contents of fish fed control (diet 1) were higher significantly than those of fish fed other diets. While fat content of fish fed control (diet 1) was lower significantly than those of fish fed other diets. The highest value of moisture, protein and ash contents was obtained on fish fed $100 \%$ FM protein control (diet 1) and the lowest was obtained on fish fed $100 \%$ PPM meal (diet 5). Incorporation of PPM in mono sex Nile tilapia diets significantly decreased moisture, protein and fat content of whole body. The highest value of lipid content was recorded with fish fed $100 \%$ PPM meal (diet 5 ) and the lowest was recorded with fish fed $100 \%$ FM protein control (diet 1) The results of El-Saidy et al. (2005) and Soltan et al. (2008) exhibited the same trend.

In conclusion, the present study revealed that plant protein mixture meal protein can replace up to $50 \%$ of fish meal protein in practical diets of mono sex Nile tilapia without any adverse effects on growth performance, feed utilization and body composition of fish. In addition, plant protein mixture meal used in the present study is available at much lower prices $(1.9 \mathrm{LE} / \mathrm{kg})$ than fishmeal $(7.75 \mathrm{LE} / \mathrm{kg})$ in many tropical and sub-tropical regions where tilapia culture is well established. Further research should be conducted under the field conditions. 
Table 5: Initial and final whole body composition of mono sex male Nile tilapia fed experimental diets. Values are mean \pm SDI of triplicate analyses.

\begin{tabular}{|c|c|c|c|c|c|c|c|c|c|c|c|c|}
\hline \multirow[b]{2}{*}{ Parameters } & \multicolumn{12}{|c|}{ Diets } \\
\hline & Initial & & 1 & & 2 & & 3 & & 4 & & 5 & \\
\hline \multirow[t]{2}{*}{ Moisture } & $78.78 \pm$ & & 74.60 & \pm & 73.02 & \pm & 72.98 & \pm & 70.88 & \pm & 69.89 & \pm \\
\hline & 0.30 & & $0.40 \mathrm{a}$ & & $0.19 b$ & & $0.63 \mathrm{~b}$ & & $0.33 \mathrm{c}$ & & $0.77 \mathrm{~d}$ & \\
\hline \multirow[t]{2}{*}{ Protein } & $12.41 \pm$ & & 56.63 & \pm & $54.74 \pm$ & & 54.16 & \pm & 53.71 & \pm & 52.93 & \pm \\
\hline & 0.29 & & $2.29 \mathrm{a}$ & & $0.09 \mathrm{~b}$ & & $0.35 b$ & & $0.31 b$ & & $0.75 b$ & \\
\hline \multirow[t]{2}{*}{ Fat } & 2.06 & \pm & 14.10 & \pm & 20.52 & \pm & 21.57 & \pm & 22.29 & \pm & 23.12 & \pm \\
\hline & 0.20 & & $0.44 \mathrm{a}$ & & $0.81 b$ & & $0.12 \mathrm{c}$ & & $0.53 \mathrm{~cd}$ & & $0.13 \mathrm{~d}$ & \\
\hline \multirow[t]{2}{*}{ Ash } & 4.42 & \pm & 17.87 & \pm & 15.52 & \pm & 15.36 & \pm & 14.52 & \pm & 12.52 & \pm \\
\hline & 0.10 & & $1.42 \mathrm{a}$ & & $0.43 \mathrm{~b}$ & & $0.33 \mathrm{~b}$ & & $0.65 \mathrm{~b}$ & & $0.09 c$ & \\
\hline
\end{tabular}

\section{Acknowledgments}

The financial support provided by the Minufiya University College of Agriculture, Shebin El-Kom, Egypt, for our fish research laboratory is greatly acknowledged.

\section{REFERENCES}

Abdelhamid, A. M., El-Fadaly, H. A. and Ibrahim, S. M. (2007). Integrated aquaculture by bearing ducks on earthen fish ponds. Aquaculture Technical Articles engormix. Com, 23p.

Abdelhamid, A. M., Salem, M. F. I and Khalafalla, M. M. E. (2006). Substitution of soybean meal by waterhyacinth hay in diets of Nile tilapia (Oreochromis niloticus). The $2^{\text {nd }}$ Inter. Sci. Con. For Environment 'Recent Environmental Problems and Social Sharement', 28 - 30 March, South Valley University. Pp: 114-126.

Abdelhamid, A. M., Salem, M. F. I and Tolan, A. E. (2004a). Evaluation of seasame meal as a dietary protein source for Nile tilapia (Oreochromis niloticus) fingerlings. J. Agric. Sci. Mansoura Univ., 29: 6887 - 6897.

Abdelhamid, A. M., Salem, M. F. I and Tolan, A. E. (2004b). Evaluation of mallow Malva parviflora L. plants as an alternative protein source for Nile tilapia (Oreochromis niloticus) fingerlings. J. Agric. Sci. Mansoura Univ., 29: 6899-6910.

Abdelhamid, A. M., Salem, M. F. I and Tolan, A. E. (2005a). Evaluation of linseed meal asa feed ingredient in diets on growing Nile tilapia (Oreochromis niloticus) .J. Agric. Res. Tanta Univ., 31 (3) : 385-402.

Abdelhamid, A. M., Salem, M. F. I and Tolan, A. E. (2005b).Utilization of black seed meal (Nigella sativa) in Nile tilapia (Oreochromis niloticus) diets) .J. Agric. Res. Tanta Univ., 31 (3) : 403-419.

AOAC (Association of Official Chemists) (1995). Official methods of analysis, $16^{\text {th }}$ edition, AOAC, Arlington, Virginia.

CAPMS (Central Agency for Public Mobilization and Statistics) (1994) Statistics of fish production in Egypt, 1994. Report no. 71-12413/92, Cairo, Egypt. 
Cho, C. Y. and Kaushik, S. J. (1985). Effect of protein intake on metabolizable and net energy values of fish diets. In: C. B. Cowey, A. M. Mackie and J. G. Bell (Editors), Nutrition and Feeding in Fish. Academic Press, London, pp. 95-117.

El-Saidy, D.M.S. (1999). Evaluation of cottonseed meal as partial and complete replacement of fishmeal in practical diets of Nile tilapia, Oreochromis niloticus (L.) fingerlings. Egypt. J. Aquat. Biol. \& Fish, 3: 441-457.

El-Saidy, D.M.S. and Gaber, M. M. A. (1997). Total replacement of fish meal by soybean meal, with various percentages of supplemental Lmethionine, in diets for Nile tilapia Oreochromis niloticus fry. Annals Agric. Se., Moshtohor, 35: 1223-1238.

El-Saidy, D. M. S. and Gaber, M. M. A. (2001). Linseed: its successful use as a partial and complete replacement for fishmeal in practical diets for Nile ti1apia (Oreochromis niloticus 1.) pages 635-642 in A.M. AbdelSamee, M.M. Shetaewi and S.I.Ghoneim, Second Inter. Conf. on Animal. Prod. \& Health in Semi-Arid Areas. Organized by Fac. Environment. Agric. Sci, Suez Canal Univ, El-Arish, North Sinai, Egypt.

El-Saidy, D.M.S. and Gaber, M.M.A. (2002a). Evaluation of dehulled sunflower meal as a partial and complete replacement for fish meal in Nile tilapia, Oreochromis niloticus (L.), diets. Pages 193-205 in Proceedings of the $1 \mathrm{~g}$ Annual Scientific Conf Anim. Fish Prod. Organized on September 24-25, 2002 by Fac Agric, Al-Mansoura Univ, Egypt.

El-Saidy, D.M.S. and Gaber, M. M. A. (2002b). Complete replacement of fish meal by soybean meal with dietary L-lysine supplement for Nile tilapia (Oreochromis niloticus) fingerlings. J. World Aqua Soc., 33: 297306.

El-Saidy, D. M. S; Magdy, M. G. and Abd -El-Shafy, A. S. A. (2005). Evaluation of Cluster bean meal, Cyamposis tetragonoloba as a dietary protein source for common carp, Cyprinus carpio, L. J. World Aquac Soc., 36: 311-319.

El-Saidy, D. M. S and. Saad, Aml. S (2008). Evaluation of Cow Pea seed meal, Vigna sinensis, as a dietary protein replacer for Nile tilapia, Oreochromis niloticus (L.) fingerlings. J. World Aquac Soc. 39: 636645.

El-Sayed, A. F. M. (1987). Protein and energy requirements of Tilapia zillii. Ph.D. Diss., Michigan State University, East Lansing, Ml, 147pp.

El-Sayed, A. F. M. (1990). Long-term evaluation of cotton seed meal as a protein source for Nile tilapia, Oreochromis niloticus (Linn.). Aquaculture, 84: 315-320.

El-Sayed, A. F. M. (1999). Alternative dietary protein sources for farmed tilapia, Oreochromis spp. Aquaculture, 179: 149-168.

Gaber, M. M. A. (1996). Partial and complete replacement of fish meal by poultry by product and feather meal in diets of Nile tilapia (Oreochromis niloticus). Annals Agric Sci, Moshtohor. 32 (1) 203-214. 
Golterman, H. L; Clymo, R. S and Ohnstad, M. A. M. (1978). Methods of Physical and Chemical Analysis of Fresh Waters. Blackwell Scientific Publications, Oxford, $214 \mathrm{pp}$.

Hasan, M. R; Macintosh, D. J. and Jauncey, K. (1997). Evaluation of some plant ingredients as dietary protein sources for common carp (Cyprinus carpio 1.) fry. Aquaculture, 151: 55-70.

Hashim, R; Saat, N. A. M. and Wong, C. H. (1994). Winged bean seed meal: its successful use as a partial replacement for fish meal in practical diets for red tilapia fry. In: The Third Asian Fisheries Forum. (ed by Chou, L. M., Munro, A. D., Lam, T. J., Chen, T. W., Cheong, L. K. K., Ding, J. K., Hooi, K. K., Khoo, H. W., Phang, V. P. E., Shim, K. F. and Tan, C. H.), pp: 660-662. Asian Fisheries Society, Manila, Philippines.

Hossain, M. A; Nahar N. and Kamal, M. (1997). Nutrient digestibility coefficients of some plant and animal protein for rohu, Labeo rohita. Aquaculture, 151: 37-45.

Jackson, A. J; Capper, B.S and Matty, A. J. (1982). Evaluation of some plant proteins In complete diets for tilapia Sarotherodon mossambicus. Aquaculture, 27: 97-109.

Mbahinzireki, G. B; Dabrowski, K; Lee, K. 1; El-Saidy, D. M. S and Wisner, E. R (2001). Growth, feed utilization and body composition of tilapia (Oreochromis sp.) fed with cottonseed meal-based diets in a recirculating system. Aquac Nutri, 7: 189-200

Middendorp, A. 1 and Huisman, E. A (1995). Pond farming of Nile tilapia, Oreochromis niloticus (L.) in northern Cameroon. Comparing two different strategies for feeding cottonseed cake in tilapia male mono sex culture. Aquac Res, 26, 731-738.

NRC, (National Research Council) (1993). Nutrient requirements of warm water fishes and shellfishes, National Academy of Sciences, Washington, DC, USA.

Santiago, C. B. and Lovell, R. T (1988). Amino acid requirements for growth of Nile tilapia. J. Nutri, 188:1540-1546.

Sanz, A; Morales, M; Higuera, de la and Cardenete, G (1994). Sunflower meal in rainbow trout, Oncorhynchus mykiss diets: Protein and energy utilization. Aquaculture, 128: 287-300.

Soltan, M. A; Hanafy, M. A and Wafa, M. I. A (2008). Effect of replacing fish meal by a mixture of different protein sources in Nile tilapia, diets. Global Veterinaria 2: 157-164.

Statistical Analysis System (SAS) (1993). SAS/STAT User's Guide, Release 6.03 edition. SAS Institute Inc. Cary. NC.

Stickney, R.R (1979). Principles of Warm water Aquaculture. Wiley Interscience, New York, USA.

Xie, S; Cui, Y; Yang, Yi and Liu, 1. (1997). Energy budget of Nile tilapia, Oreochromis niloticus in relation to ration size. Aquaculture, 154: 5768.

Zar, 1. H (1984). Bio-statistical Analysis, $2^{\text {nd }}$ edit. Prentice-Hall Int, Inc. En Englewood Cliffs, New Jersey, USA. 
El-Saidy, D. M. S. et al.

الاحلال الجزئى والكلى لمسحوق السمك بمخلوط من مصادر مختلفة من البروتينات

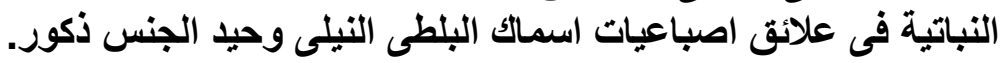

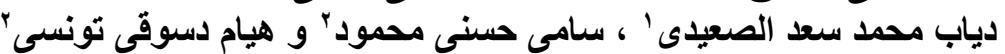

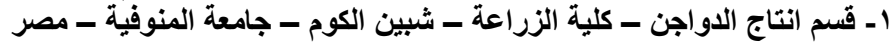

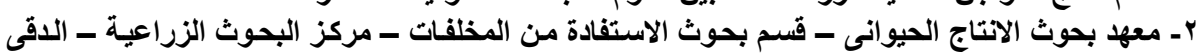

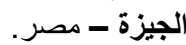

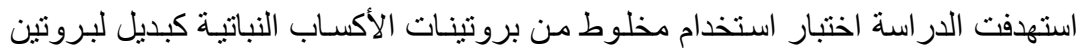

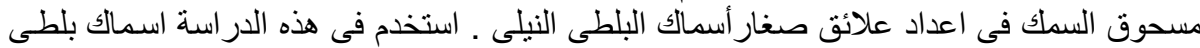

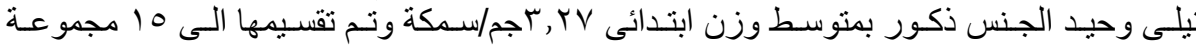

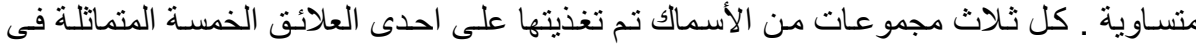

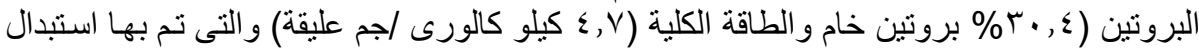

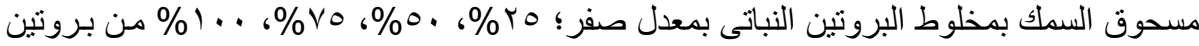

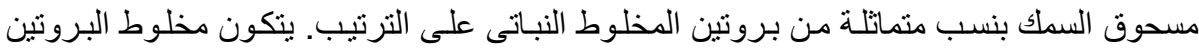

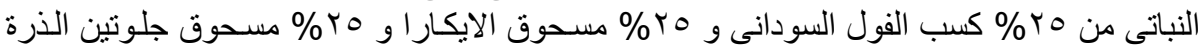

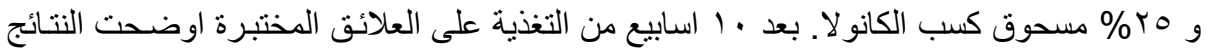

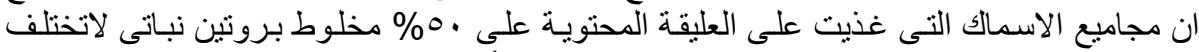

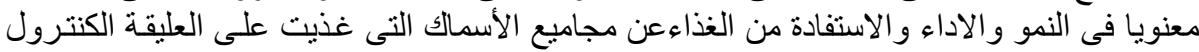

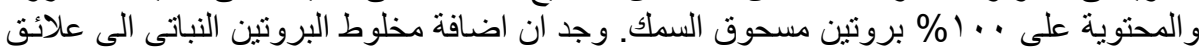

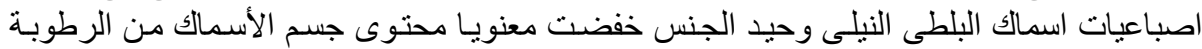

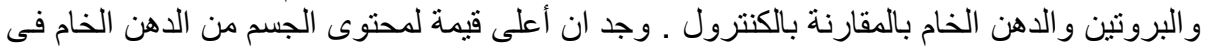

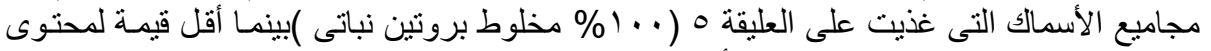

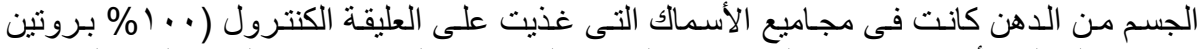

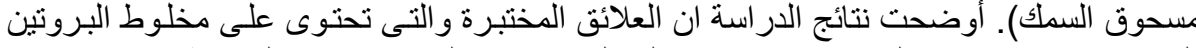

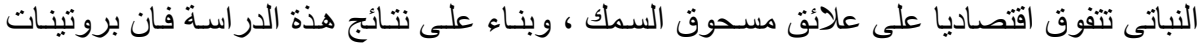

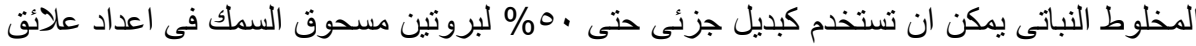
اسماك البلطى النيلى وحيد الجنس دون أى تأثيرات عكسية على النمو و الأداء و الاستفادة من الغذاء الغذاء

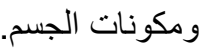

